\section{Regards sur l'économie allemande}

Bulletin économique du CIRAC

$86 \mid 2008$

Varia

\title{
Portrait social
}

BÄCKER Gerhard, NAEGELE Gerhard, BISPINCK Reinhard, HOFEMANN

Klaus et NEUBAUER Jennifer, Sozialpolitik und soziale Lage in

Deutschland. Vol. 1 : Grundlagen, Arbeit, Einkommen und Finanzierung ; vol. 2 : Gesundheit, Familie, Alter und soziale Dienste

\section{(2) OpenEdition}

\section{Journals}

Édition électronique

URL : http://journals.openedition.org/rea/764

DOI : $10.4000 /$ rea. 764

ISBN : 978-2-8218-0868-3

ISSN : 1965-0787

Éditeur

CIRAC

Édition imprimée

Date de publication : 1 mai 2008

ISSN : 1156-8992

Référence électronique

«Portrait social », Regards sur l'économie allemande [En ligne], 86 | mai 2008, document 6, mis en ligne le 14 mai 2008, consulté le 22 septembre 2020. URL : http://journals.openedition.org/rea/764 ; DOI : https://doi.org/10.4000/rea.764

Ce document a été généré automatiquement le 22 septembre 2020.

(c) CIRAC 


\section{Portrait social}

BÄCKER Gerhard, NAEGELE Gerhard, BISPINCK Reinhard, HOFEMANN

Klaus et NEUBAUER Jennifer, Sozialpolitik und soziale Lage in

Deutschland. Vol. 1 : Grundlagen, Arbeit, Einkommen und Finanzierung ; vol. 2 : Gesundheit, Familie, Alter und soziale Dienste

\section{RÉFÉRENCE}

BÄCKER Gerhard, NAEGELE Gerhard, BISPINCK Reinhard, HOFEMANN Klaus et NEUBAUER Jennifer, Sozialpolitik und soziale Lage in Deutschland. Vol. 1 : Grundlagen, Arbeit, Einkommen und Finanzierung ; vol. 2 : Gesundheit, Familie, Alter und soziale Dienste, VS Verlag für Sozialwissenschaften, Wiesbaden, $4^{\mathrm{e}}$ édition, 2008,624 et $616 \mathrm{p}$.

1 Emploi, degré de protection des salariés, état de santé, natalité, situation familiale, démographie, services sociaux, revenus, réglementation du travail, politique sociale voilà, en vrac, quelques-uns des thèmes abordés dans cette 'germanoscopie' présentant l'état de la société allemande. S'y ajoutent la description de l'état du droit social, l'évolution de la politique sociale, ainsi que l'étude des enjeux de la modernisation du modèle social allemand dans son contexte européen. Ce grand classique parmi les manuels qui s'adresse aussi bien aux politologues qu'aux sociologues connaît là sa 4 ème édition, entièrement revue et actualisée. Une référence aussi pour quiconque est en quête d'un aperçu du droit, d'une présentation des acteurs et des termes du débat actuel en la matière. (ib) 